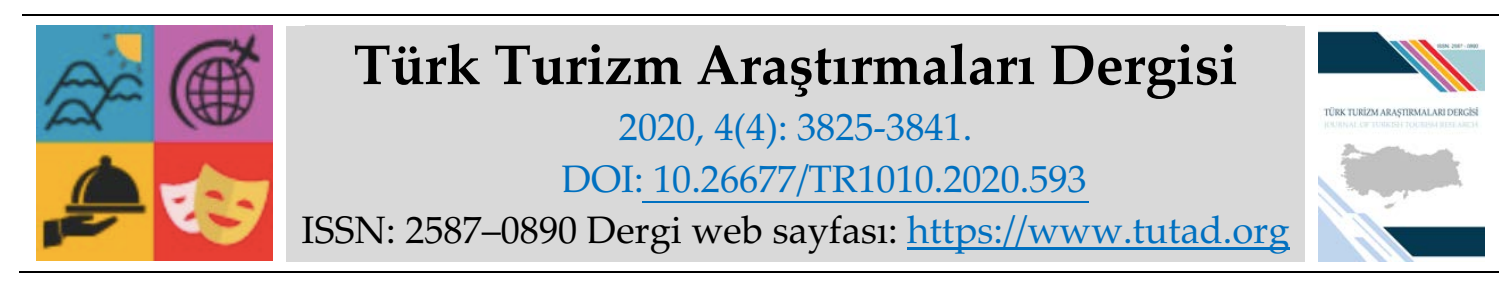

ARASTIRMA MAKALESI

\title{
Kültür ve İnanç Turizmi Kapsamında Ziyaretçilerin Seyahat Profillerinin İncelenmesi: Sille Örneği
}

Öğr. Gör. Dr. Münevver Çİ̧EKDAĞI, Selçuk Üniversitesi, Turizm Fakültesi, Konya, e-posta: mcicekdagi@selcuk.edu.tr

ORCID: https://orcid.org/0000-0001-8195-1542

Öz

Ziyaretçilerin belli bir bölge üzerindeki seyahat davranışlarını anlamak, o bölgeye gelenlerin profilini ortaya çıkarmak bakımından önemlidir. Tespit edilen seyahat profillerine göre yeni turizm planları oluşturulabilecek, uygulamalarla bölgede daha fazla ziyaretçi ağırlanması mümkün olabilecektir. Çalışmanın amacı; önemli bir kültür ve inanç merkezi olan Sille'yi ziyaret edenlerin elektronik yorumlarını analiz ederek bölge turizminin geliştirilebilmesi noktasında yöneticilere öneriler sunarak katkı sağlamaktır. Bu kapsamda çalışmada altı soruya cevap aranmıştır. Çalışmada kullanılan veriler TripAdvisor isimli sitede yer alan, 2014-2020 yıllarını kapsayan 618 elektronik yorumdan oluşmaktadır. Yorumlar MAXQDA isimli veri analizi programında analiz edilmiştir. Analiz neticesinde ziyaretçilerin daha çok" bilgeci" tipten oluştuğu, ziyaretlerin en çok "Ağustos" ayında ve "aile" ile gerçekleştiği görülmüştür. Sille'nin "merkeze yakınlığı" öne çıkan olumlu görüş olurken "restorasyonların kötü bulunması" olumsuz görüşlerin başında gelmiştir En dikkat çekici konum "Aya Elenia Kilisesi" olmuştur ve Sille en fazla "Kapadokya" bölgesine benzetilmiştir.

Anahtar Kelimeler: Seyahat Profili, Sille, Veri Analizi, MAXQDA.

Makale Gönderme Tarihi: 25.07.2020

Makale Kabul Tarihi: 09.10.2020

\section{Önerilen Atıf:}

Çiçekdağı, M. (2020). Kültür ve İnanç Turizmi Kapsamında Ziyaretçilerin Seyahat Profillerinin İncelenmesi: Sille Örneği, Türk Turizm Araştırmaları Dergisi, 4(4): 3825-3841.

(C) 2020 Türk Turizm Araştırmaları Dergisi. 


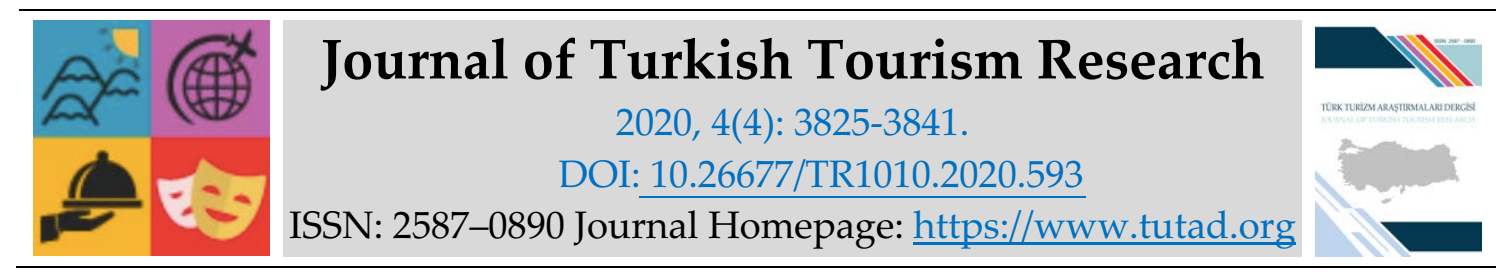

\title{
$\underline{\text { RESEARCH PAPER }}$
}

\section{Examination of Travel Profiles of Visitors within the Scope of Culture and Faith Tourism: The Example of Sille}

\author{
Dr. Münevver Çı̇ÇEKDAĞI, Selçuk University, Faculty of Tourism, Konya, e-mail: \\ mcicekdagi@selcuk.edu.tr \\ ORCID: https://orcid.org/0000-0001-8195-1542
}

\begin{abstract}
Understanding the travel behavior of visitors in a certain region is important in terms of revealing the profile of those who come to that region. New tourism plans can be created according to the determined travel profiles, and it will be possible to host more visitors in the region with applications. Purpose of the study; To analyze the electronic comments of visitors to Sille, which is an important center of culture and belief, and to contribute to the managers by offering suggestions to develop regional tourism. In this context, answers to six questions were sought in the study. The data used in the study consists of 618 electronic comments covering the years 20142020 on the website named TripAdvisor. The comments were analyzed in a data analysis program called MAXQDA. As a result of the analysis, it was seen that the visitors were mostly of the "wise" type, and the visits were mostly made in "August" and with "family". While Sille's "proximity to the center" was the prominent positive opinion, "the restorations were bad" was the leading negative opinion. The most striking location has been the "Aya Elenia Church" and Sille has been mostly compared to the "Cappadocia" region.
\end{abstract}

Keywords: Travel Profile, Sille, Data Analysis, MAXQDA.

Received: 25.07.2020

Accepted: 09.10.2020

\section{Suggested Citation:}

Çiçekdağı, M. (2020). Examination of Travel Profiles of Visitors within the Scope of Culture and Faith Tourism: The Example of Sille, Journal of Turkish Tourism Research, 4(4): 3825-3841.

(c) 2020 Türk Turizm Araştırmaları Dergisi. 


\section{Gíriş}

Ziyaretçi özelliklerinin tespit edilmesi; turizmi geliştirme planlarının hazırlanmasında, turistik ürünün şekillenmesinde ve turistik taşıma kapasitesinin belirlenmesinde önemli rol oynamaktadır (Avcıkurt, 2003: 22). Modern pazarlama faaliyetlerde esas niyet müşteri tatminini sağlayarak kâr sağlamak olduğuna göre destinasyon pazarlaması yapılırken de gelen turistin profilinin belirlenmesi büyük önem taşımaktadır (Belber, 2011: 32). Sosyal medya web siteleri, kullanıcıların etkileşimli Web 2.0 teknolojileri ve uygulamaları (Ör. Facebook, Twitter, TripAdvisor, vb.) yoluyla bilgi ve deneyimler oluşturmasına ve dağıtmasına olanak tanır. Bu durum, tweetler, görüşler ve incelemeler gibi çevrimiçi kullanıcı üretimi içeriklerde bir patlamaya yol açmıştır. Bununla birlikte, bu kadar büyük miktarda yapılandırılmamış ve yarı yapılandırılmış veri, veri analizi için zorluklara ve fırsatlara da yol açar. (Chang vd., 2019: 264). Günümüz dijital ortamında ziyaretçiler gittikleri yerlerle ilgili birçok sosyal paylaşım platformu üzerinden tavsiye ve eleştiri niteliği taşıyan görüşlerini paylaşmaktadırlar. Bu elektronik yorumlar doğru bir şekilde analiz edildiğinde gidilen yere ait ziyaretçilerin seyahat profillerinin tespiti yapılabilmektedir.

Dünya genelinde tarihi özelliğe sahip kentler turizm potansiyeli yüksek yerler haline gelmiştir. Tarihi ve kültürel değerleri ile ön plana çıkmış olan alternatif turizm merkezlerinden biri de Konya'dır (Tapur, 2009a: 475). Konya için Sille bir turizm koridoru olup tarihi ve kültürel açıdan oldukça zengin bir yerleşkedir. Sille, sahip olduğu değerlerini geçmişten günümüze yaşatıp, varlığını korumuş olan bir turizm bölgesidir. (Ertaş vd., 2016: 196). Günümüze dek yerli ve yabancı birçok ziyaretçi ağırlayan Sille, sosyal paylaşım platformlarında sıklıkla hakkında yorum yapılan merkezlerden bir tanesidir.

Çalışmanın konusu; Konya İl'indeki önemli kültür ve inanç turizm merkezlerinden biri olan Sille hakkında ziyaretçilerin elektronik yorumlarının analizidir. Çalışmanın amacl; önemli bir kültür ve inanç merkezi olan Sille'yi ziyaret edenlerin elektronik yorumların analiz ederek bölge turizminin geliştirilebilmesi noktasında yöneticilere öneriler sunarak katkı sağlamaktır. Bu kapsamda öncelikle kültür ve inanç turizmi hakkında yazın incelemesi yapılmıştır. Ardından kültür ve inanç turizmine katılan ziyaretçilerin seyahat profilleri konusuna değinilmiştir. Daha sonra araştırmaya konu olan Sille hakkında bilgi verilmiştir. Son olarak Sille ziyaretçilerinin sosyal paylaşım platformundaki yorumları kodlamalara tabi tutularak veri analiz programı vasıtası ile analiz edilerek seyahat profilleri ortaya çıkarılmaya çalışılmıştır.

\section{KAVRAMSAL ÇERÇEVE}

Çalışmada kültür turizmi, inanç turizmi, ziyaretçilerin seyahat profilleri ve kültür ve inanç turizm merkezi olan Sille hakkında literatür incelemeleri yapılmıştır.

\section{Kültür ve İnanç Turizmi}

Kültür ve turizm her zaman ayrılmaz bir şekilde bağlantılı olmuştur. Kültürel manzaralar, cazibe merkezleri ve etkinlikler seyahat için önemli bir motivasyon sağlar ve seyahat kendi içinde kültür oluşturur. Ancak son yıllarda kültür ve turizm arasındaki bağlantı, belirli bir tüketim biçimi olarak daha açık bir şekilde tanımlanarak kültür turizmi olarak karışımıza çıkmıştır (Richards, 2018: 12).

İnsanların sürekli ikamet ettikleri, çalıştıkları ve olağan ihtiyaçlarını karşıladıkları yaşam alanlarının dışında, dini inançlarını yaşayabilmek ve inanç merkezlerini görebilmek amacıyla 
yaptıkları turistik gezilerin turizm kapsamında incelenmesi "İnanç Turizmi" olarak tanımlanmaktadır (T.C. Kültür ve Turizm Bakanlığı).

İnanç turizmine konu olan turizm çekicilikleri zaman zaman kültürel amaçlı olarak da ziyaretçi ağırlayabilmektedir. Bu da kültür ve inanç turizmleri arasında sıkı bir bağ olduğunu göstermektedir. Bunun sebebi ise kültürlerin oluşmasında dinlerin önemli bir yerinin olmasıdır. Ziyaretçiler gittikleri bölgedeki insanların dini davranışlarını incelerken aynı zamanda kültürleri hakkında bilgi sahibi olabilirler. Dolayısıyla kültür ve din kavramları birbirleriyle yakından ilişkilidir. İnanç turizmine yönelik yapılan seyahatler sayesinde bölge kültürü de gözlemlenebilmektedir. Diğer turizm türlerine kıyasla inanç turizminde ziyaretçilerin inançlarıyla ilgili yerleri birden fazla kez ziyaret ettikleri söylenebilir. Bu da inanç turizmini potansiyeli yüksek bir alternatif turizm şekli olarak karşımıza çıarmaktadır (Keskin ve Çetinkaya, 2018: 300-301).

Türkiye, dünyadaki konumu sebebiyle kültür ve inanç turizmi bakımından oldukça zengindir. Sahip olduğu inanç turizmi değerleri ile Anadolu, insanlara ortak değerlerini göstermekte, yaradılış kardeşliğinde buluşturmaktadır (Kaynak, 2010: 122). Üç semavi din olan Musevilik, Hristiyanlık ve İslamiyet Anadolu topraklarında gelişmiştir. Bu dinlerin etkileri Anadolu'dan tüm dünyaya yayılmıştır. Bıraktıkları eşsiz eserler, üç semavi din mensupları için önemli olup, günümüze kadar korunarak büyük bir inanç turizmi potansiyeli oluşturmaktadır (Kuyucu, 2017: 27).

İnanç turizmi pazarının artan dinamikleri, karmaşıklığı ve bunun yanı sıra turizm işletmecilerin bu pazarı homojen olarak nitelendirmeleri birtakım sorunlar ortaya çıkarmaktadır. Bilimsel bilginin artması inanç turizmi pazarını bölümlendirmek için önemli görülmektedir. Bu bilgilerle inanç merkezlerinin yöneticileri, işletmeleri ve destekleyicileri yönlendirilebilecektir (Drule vd., 2015: 269).

\section{Ziyaretçilerin Seyahat Profilleri}

Çalışmada turist kavramı yerine ziyaretçi kavramı üzerinde durulmuştur. Bunun sebebini açıklamak için bazı tanımlar yapmak gerekmektedir. 22747 sayılı Seyahat Acenteleri Yönetmeliği'nde turist; "para kazanma amacı olmaksızın dinlenmek ve eğlenmek için ya da kültürel, bilimsel, sportif, idari, diplomatik, dinsel, sihhi ve benzeri nedenlerle, oturduğu yer dışına geçici olarak çıkan ve tüketici olarak belirli bir süre seyahat edip kalan ve yeniden ikametgâhnna dönen kimsedir" şeklinde tanımlanmaktadır. Bilhassa turizm istatistikleri tutulurken bazı kavram karmaşaları yaşanabilmektedir. Turist, ziyaretçi, günübirlikçi kavramları sıklıkla birbirlerinin yerine kullanılabilmektedir. Ancak aralarında birtakım farklılıklar bulunmaktadır. Bu farklılıkları görmek için aşağıda ziyaretçinin tanımı yapılmıştır.

Ziyaretçi, ülkede veya ziyaret edilen yerde ikamet eden bir tüzel kişilik tarafından istihdam edilmek dışında herhangi bir ana amaç (iş, eğlence veya diğer kişisel amaçlarla) için bir yıldan daha az süreyle olağan ortamının dışında bir ana varış noktasına seyahat eden bir yolcudur. Ziyaretçilerin yaptıkları bu geziler turizm gezisi niteliğindedir. Turizm, ziyaretçilerin faaliyetlerini ifade eder. Bir turizm gezisindeki yerli, gelen veya giden yolcu, sırasıyla yurtiçi, gelen veya giden ziyaretçi olarak adlandırılır. Ayrıca, yurtiçi, gelen veya giden ziyaretçilerin seyahatlerine sırasıyla yurtiçi, gelen veya giden turizm denir. Bu nedenle turizm, seyahatin bir alt kümesidir ve ziyaretçiler, gezginlerin bir alt kümesidir. Bu ayrımlar, gezginlerin ve ziyaretçilerin akışlarına ilişkin verilerin derlenmesi ve turizm istatistiklerinin güvenilirliği açısından çok önemlidir. Bir ziyaretçi (yurtiçi, gelen veya giden), gezisi bir gecelik konaklamayı içeriyorsa turist (veya geceleme ziyaretçisi), aksi takdirde aynı gün (günübirlik) ziyaretçi (veya 
gezici) olarak sınıflandırılır (United Nations, 2010: 10). Sille'ye gelenler de bölgede konaklama yapmayıp günü birlik gelip gittikleri için turist ifadesi yerine ziyaretçi ifadesinin kullanılmasının daha doğru olacağı düşünülmüştür.

Günümüzde birçok çalışma turistlerin seyahat motivasyonlarını ve turist tiplerini incelemiştir. Ancak bu çalışmada ziyaretçilerin seyahat profilleri üzerinde durulmaktadır. Bu kapsamda turist tiplendirmesinin yanı sıra seyahatlerini yılın en çok ve en az hangi aylarında yapmayı tercih ettikleri ile kimlerle seyahat ettikleri konuları üzerinde durulmuştur. Bilindiği üzere turist kitleleri daha çok sıcak mevsimlerde, okulların tatil olduğu dönemlerde seyahatlerini gerçekleştirmektedir. Ayrıca turistik çekiciliğin yanı sıra birçok faktöre göre seyahatlerin bireysel, grup veya kitlesel olarak farklı biçimlerde gerçekleştiği görülebilmektedir. Çalışma seyahat profilleri konusunda turist tipi, seyahat zamanı ve kimlerle seyahat edildiği ile sınırlandırılmıştır.

Turistik tüketicilerin tiplendirilmesi; tüketicilerin öğrenilmesi, turistik işletmelerin yönetilmesi ve turizm planlaması için oldukça önemlidir. Kapsamlı ve yararlı bir turist tiplendirmesi yapılırken birbirine çok benzeyen boyutlar farklı isimlerle ortaya konulabilmektedir. Boyutlar birleştirme, daha açık ifade edilme gibi çalışmalarla daha anlamlı, kullanışlı ve yararlı hale getirilebilmektedir. Günümüze dek turistler çok çeşitli şekillerde sınıflandırılmaya çalışılmıştır. Çalışma kapsamında ele alınan Plog'un 1995 yılında yaptığı detaylı tiplendirme şu şekildedir (Rızaoğlu, 2012: 215-217):

1. Serüvenciler: Sorma ve araştırmayı severler. Bir çekim yerine gidenler arasında ilk olmaya önem verirler.

2. Zevk Arayıcılar: Turistik bir ziyaretin ulaşım, konaklama, eğlence gibi tüm aşamalarında lükse önem verirler ve rahatlık ararlar.

3. Vurdumduymazlar: Plan yapmadan ansızın ve çabuk bir şekilde seyahat kararı verme eğilimindedirler.

4. Özgüvenciler: Sıra dışı çekim yerlerine gitmek isterler ve çok farklı etkinliklere katılma taraftarıdırlar.

5. Planlayıcılar: Tatillerinin her aşamasının önceden planlanmasını severler. Önceden planlanmış tur programlarını tercih edebilirler.

6. Erilciler: Aktif hareket etmeyi severler. Kamp yapma, avcılık, balık tutma gibi daha çok açık hava etkinliklerini tercih ederler.

7. Bilgeciler: Gittikleri yerlerdeki tarihi ve kültürel bilgilere önem verirler, tatillerinden bilgilenmiş şekilde dönerler.

8. Öteki Yönlüler: Dışa dönük tipte olup tatilleri boyunca karşılaştıkları kişilerle samimi bir ilişki kurmak isterler.

\section{Önemli Bir Kültür ve İnanç Turizm Merkezi Olarak Sille}

Konya, çok sayıda medeniyeti ağırlamış, doğal güzelliklere de sahip bir beldedir. Bu açıdan yaklaşıldığında alternatif turizm olanaklarının oldukça fazla olduğu görülmektedir. Arkeolojik kalıntılar, anıtlar, ören yerleri, kentsel ve doğal sit alanları, höyükler, külliye, cami, kilise, han, hamam gibi birçok tarihi değerlere sahiptir. Bunun yanı sıra yemek, gelenek görenek, folklor gibi kültürel değerleri önemli turizm kaynaklarındandır. M.Ö. 5500 yıllarına ait yerleşim yerlerinden Hristiyanlığın ilk ibadethanelerine dek çok kıymetli eserler ve yapılar barındırmaktadır. İnsanoğlunun ilk yerleşim yerlerinden olan Çatalhöyük başta olmak üzere, kilise, manastır, cami 
ve konutları ile Sille, Kilistra, İvriz kabartmaları, Eflatunpınar kültür turizmi açısından önemli noktalardır (Tapur, 2009a: 476-477).

Konya'nın 8 km kuzeybatısında, antik bir Rum yerleşkesi olarak kurulan Sille'nin en eski yerleşim yeri Sızma Höyüğü'dür (www.konyakultur.gov.tr; Tapur, 2009b: 16). Bölgede Frig uygarlığından kalan kalıntılar ile Roma mimarisine ait taş yapılar bulunmaktadır. Kral Yolu'na gidenler için bir uğrak nokta olmuştur. Bizans'ın başkentinin İstanbul olduğu dönemde İstanbul'dan Kudüs'e hac için gidenlerin de uğrama noktası olmuştur. Büyük Konstantin'in annesi olan Hristiyan Aristorat Helene Hz. İsa'nın gerildiğine inanılan kutsal haçı bulmak için Kudüs'e gitmiş ve geçtiği yollara kiliseler inşa ettirmiştir. Sille'deki Aya Elenia Kilisesi de bu yol üzerinde bulunan, Helene' nin yaptırdığı kiliselerden bir tanesidir. Selçuklular' in 1071 yılından sonra Konya'yı başkent yapmaları ile Sille'nin önemi artmıştır. Bu dönemde Gayrimüslimlerin bir kısmının Konya içinden Sille'ye göç ettiği sanılmaktadır (www.konyakultur.gov.tr).

Sille hakkındaki belgeler incelendiğinde yaşam üç ana dönemde incelenebilmektedir (Özönder, 1999: 535):

- Hristiyanlık öncesi dönem: Etiler ve Sümerler dönemini kapsar.

- Hristiyanlık dönemi: Kazmaya elverişli dağ ve tepeleri ile ilk Hristiyanlar'ın sığınak ve mabetlerine ev sahipliği yapmıştır. Döneme ait mağara, manastır ve kaya kiliseleri halen mevcuttur. Aziz Pavlos'un yaşamından izler ve eserler bölgede rahatlıkla incelenebilmektedir.

- İslamiyet dönemi: Müslüman Arap halkının bölgede zaman zaman bulunmasına karşılık, Konya (İconium) ve çevresi Selçuklular zamanında Müslüman Türk yurdu olmuştur. Sille yakınındaki Gevele Kalesi'nin fethedilmesiyle birlikte Rumlar kaleden çıkarılmış, onlarla birlikte teslim olan Bizans halkı da Sille'de yaşamıştır (Hamilton, 1842); aktaran Özönder, 1999: 536).

1989 yılında Sille Konya'nın Merkez ilçesi Selçuklu' ya iki mahalle şeklinde bağlanmıştır. 1995 yılında ise Konya Kültür ve Tabiat Varlıklarını Koruma Kurulu tarafından mezarlık, manastır ve kilisenin bulunduğu güney yamaçlar birinci derece arkeolojik sit alanı ilan edilmiştir. Diğer yerleşim yeri ise kentsel sit alanı olarak ilan edilmiştir (www.konyakultur.gov.tr).

Sille, otantik mimari dokusu, doğal güzellikleri ve derin kültür birikimi ile Bizans döneminden günümüze varıncaya dek halen mesire alanı olması ile meşhurdur. Turizm açısından yaklaşıldığında Sille' de Hristiyanlık dönemine ait manastır ve kiliseler bulunurken; Selçuklu ve Osmanlı dönemlerine ait ise camiler, köprüler, hamamlar ve çeşmeler bulunmaktadır. Bu kıymetli eserlerden bazıları şu şekilde listelenebilir (Tapur, 2009b: 26-30):

- Camiler: Mezarkayası Camii, Çay Camii, Orta Mahalle Camii, Karataş Camii, Ak Camii, Kurtuluş Camii, Subaşı Camii.

- Kiliseler: Aya Elenia Kilisesi, Ak Manastır, Çevrikler Kilisesi, Mezarlık Kilisesi, Hıdırellez Kilisesi, Aşağı Kilise, Kızıl Kilisesi.

- Hamamlar: Hacı Ali Ağa Hamamı, Şubaşı Hamamı.

- Çeşmeler: Karataş, Ankereki, Stefan, Çevrikler, Hereki, Kavaklı, Hassi Oğlu, Nuri Paşa, Çeve Oğlu, Hacı İsmail Ağa, Hacı Şaban, Bardakçı, İkili, Takkacı, Sadettin, Kavaklı, Çay.

Literatür incelemesi neticesinde; tarım, hayvancllık, bağcllık gibi ekonomik faaliyetlerin de görüldüğü Sille'nin, sahip olduğu taş işçiliği, halıcıllğı, çömlek ve testi üretimi, mumculuk faaliyetleri, mimarisi, kendine has mutfağ 1 ve derin tarihi ile birçok bilimsel çalışmaya, çalıştaya, seminer ve kongrelere konu olduğu görülmektedir.

Sille, barındırdığı çok sayıda kültürel çekicilik sayesinde kültür turizmi, inanç turizmi, kırsal turizm, gastronomi turizmi, foto-safari gibi birçok turizm türü ilgililerine ev sahipliği yapmaktadır (Üzümcü vd., 2017: 59). Bu turizm çeşitlerine ilgi duyan yüzlerce ziyaretçi her yıl 
Sille'ye gelmektedir. Gelen ziyaretçiler bölge hakkındaki olumlu ve olumsuz her türlü görüşlerini seyahat deneyimi paylaşma platformlarına yazmaktadırlar. Bu yorumlar bölge hakkında aklında soru işareti olan potansiyel ziyaretçilere bir anlamda rehber olma niteliği taşıdığından önem arz etmektedir.

\section{YÖNTEM}

\section{Araştırmanın Yöntemi}

Çalışmanın amacl; önemli bir kültür ve inanç merkezi olan Sille'yi ziyaret edenlerin elektronik yorumlarını analiz ederek bölge turizminin geliştirilebilmesi noktasında yöneticilere öneriler sunarak katkı sağlamaktır. Araştırmanın amacı doğrultusunda katılım sağlayanların görüşlerinin içeriklerini sistemli bir şekilde tanımlamayı sağladığı için (Altunışık vd., 2015: 324) ve toplanmış olan verileri açıklamaya yardım edecek ilişkilere ve kavramlara ulaşma olanağı tanıdığı için (Karataş, 2015: 74), nitel araştırma tekniklerinden biri olan içerik analizi tercih edilmiştir. İçerik analizi, metinlerden veya anlamlı diğer verilerden, kullanım durumları doğrultusunda geçerli çlkarımlar yapabilmek amacıyla kategorilere içeriklerin yerleştirilmesi ile kullanılan bir araştırma türüdür (Krippendorff, 2004: 18). İçerik analizi yöntemi örneklem bağlamında verinin içeriğinden hareket ederek, sezgisel olarak anlam taşıyan çıkarımlar yapılmasını sağlamaktadır (Doğan ve Ertan, 2016: 144) Araştırmanın verileri popüler bir seyahat sitesi olan TripAdvisor.com'dan alınmıştır. Seyahat deneyimlerinin kullanıcılar tarafından paylaşıldığ 1 internet siteleri incelendiğinde; 'TripAdvisor', dünyanın en çok kullanıcısı olan seyahat içeriğine sahip satış ve içerik sitesidir. Seyahat edenlerin 'TripAdvisor' isimli siteyi kullanmalarındaki temel neden ise "ilham almaktır" (Eröz ve Doğdubay, 2012: 145). Bu kapsamda veri analizi yapılan konum olarak Şekil 1'de görülen "Sille Köyü" seçilmiştir. Bu konum TripAdvisor sitesinde aynı zamanda “Travellers' Choice" olarak yani "Seyahat Edenlerin Tercihi” ödülünü almış ve TripAdvisor sitesinin tanımına göre TripAdvisor'daki işletmeler arasında ilk \%10'luk dilimde yer alan gezilecek yer olarak ödüllendirilmiştir. Site üzerindeki yorumlar Aralık 2014 tarihinden itibaren başladığı için çalışma 2014-2020 yılları arasındaki 618 elektronik yorumla sınırlı kalmıştır. Araştırmada öncelikle Aralık 2014 tarihinden Temmuz 2020 tarihine kadar yer alan tüm yorumlar Word ortamına alınarak, yazım ve dilbilgisi hataları düzeltilmiştir. Site farklı dillerden yapılan elektronik yorumları otomatik olarak Türkçe'ye çevirmiş olup çoğunluğu İngilizceden oluşan 13 farklı dilden Türkçe'ye çevrilen toplam 618 elektronik yorumun tamamı içerik analizine tabi tutulmuştur. Araştırmanın amacı doğrultusunda elde edilen ikincil verileri analiz etmede MAXQDA 20 programından faydalanılmıştır. MAXQDA programında veriler öncelikli olarak alt kodlar halinde kodlanmakta, sonrasında ise alt kodlar kategoriler haline dönüştürülerek analizler yapılmaktadır. Araştırmanın güvenilirliğinin sağlanması amacıyla verilerden elde edilen alt kodlar ve bu kodların oluşturmuş olduğu kategoriler, başka akademisyenler ve uzman görüşlerine başvurularak uyum ve fikir birliği sağlanarak araştırmanın güvenirliliğinin oluştuğu varsayılmıştır.

Bu kapsamda aşağıdaki araştırma sorularına cevap aranmıştır:

1. Ziyaretçiler Sille'yi yılın en çok ve en az hangi aylarında ziyaret etmektedirler?

2. Hangi tip ziyaretçiler Sille'yi daha çok ziyaret etmektedirler?

3. Sille hakkındaki olumlu ve olumsuz düşünceler nelerdir?

4. Sille içinde dikkat çekici konumlar nerelerdir?

5. Sille ile karşılaştırılan benzer destinasyonlar nerelerdir?

6. Ziyaretçiler seyahatlerini kimlerle gerçekleştirmektedirler? 


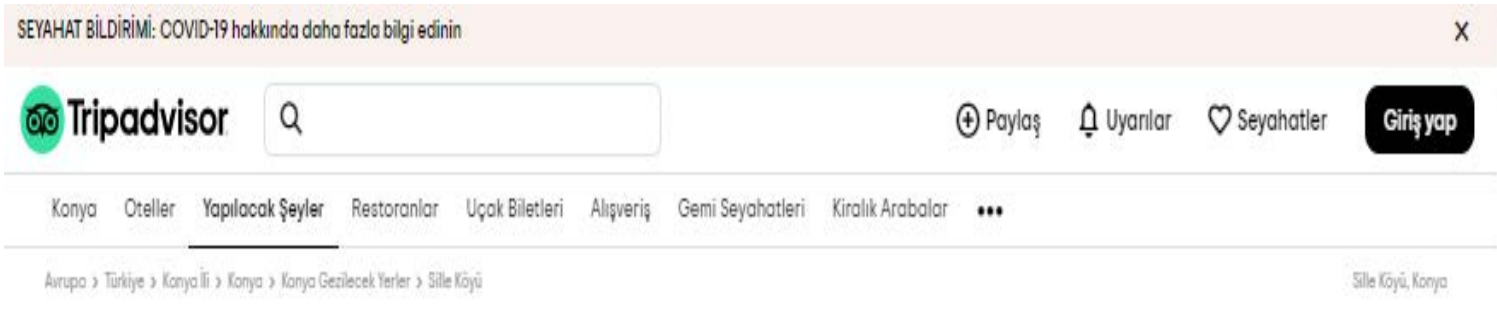

\section{Sille Köyü \\ 00000 bil Yorum}

yopilocok \$ey - 62 içerisinde 6. - Konyo

Merkezi ve ilgi Cekici Noktolar

Seyahat edenler ne diyor

"Güzel köy"

Sille Köyü Konyo merkeze yaklaģik 10 km uzakilkto. Köyün girizinde ücretsiz otopark vor:Zaten köye or...Devomin! okuyun

OOOO Yorum Tarihi: 12 Tenmus 2020

$9 \mathrm{koj}$

"Mūkemmel bir tarihi köy"

Köy şohane. Bol miktordo kofe ve kohwoltu mekanlar!

vor. Torihi çok eskilere dayoniyor. Konyo

merkez. Devomini okuyun

OeOP Yorum Tarihi: 10 Tenmuz 2020

Tum yorumion gōster:

$\theta$ Bu Koydl Geliģ̧irin

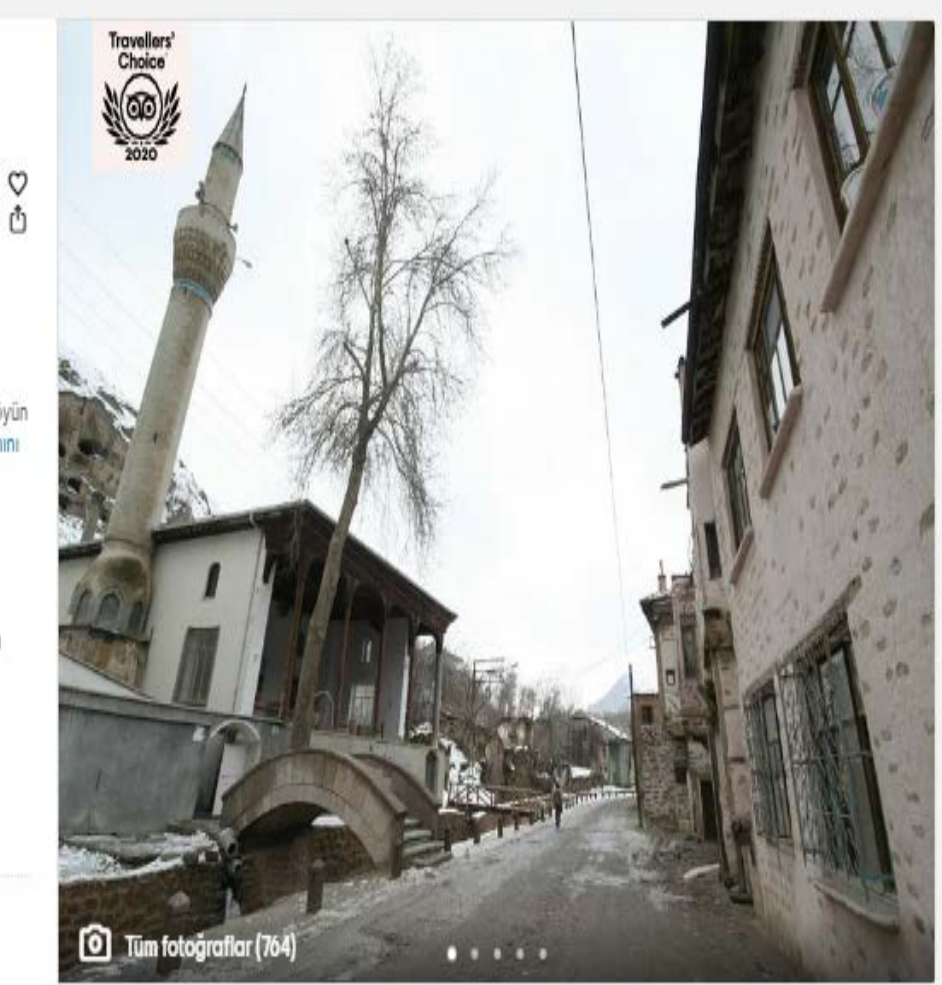

Şekil 1. Tripadvisor Sitesinde Sille Köyü Sayfasına Ait Ekran Görüntüsü

\section{BULGULAR}

Araştırma kapsamında elde edilen bulgular sırasıyla aşağıdaki bölümlerde açılanmaya çalışılmıştır. Şekil 2'de elektronik yorumları yapan kişilerin seyahat ettikleri aylar kodlanmıştır. Toplam kodlanan kodların sayısı 513 olup yılın 12 ayını kapsamaktadır. Şekil 2 incelendiğinde yapılan yorumlara göre; kış ayları olan Aralık, Ocak ve Şubat aylarında seyahat sayılarında düşüş olduğu, havalar ısındıkça seyahat sayılarının arttığı, aynı zamanda Ağustos ayının yılın en çok seyahat edilen ayı olduğu görülmektedir. Bu durum özellikle açık havada gezilebilecek bir konum olan Sille'nin ziyaretçiler tarafından havaların isınmasıyla doğru orantılı olarak tercih edildiğini göstermektedir. Sille için kış aylarında turist getirici etkinliklerin planlanması ile daha fazla ziyaretçi gelebileceği düşünülmektedir. 


\section{Ziyaretçilerin Sille'yi En Çok ve En Az Ziyaret Ettiği Aylar}

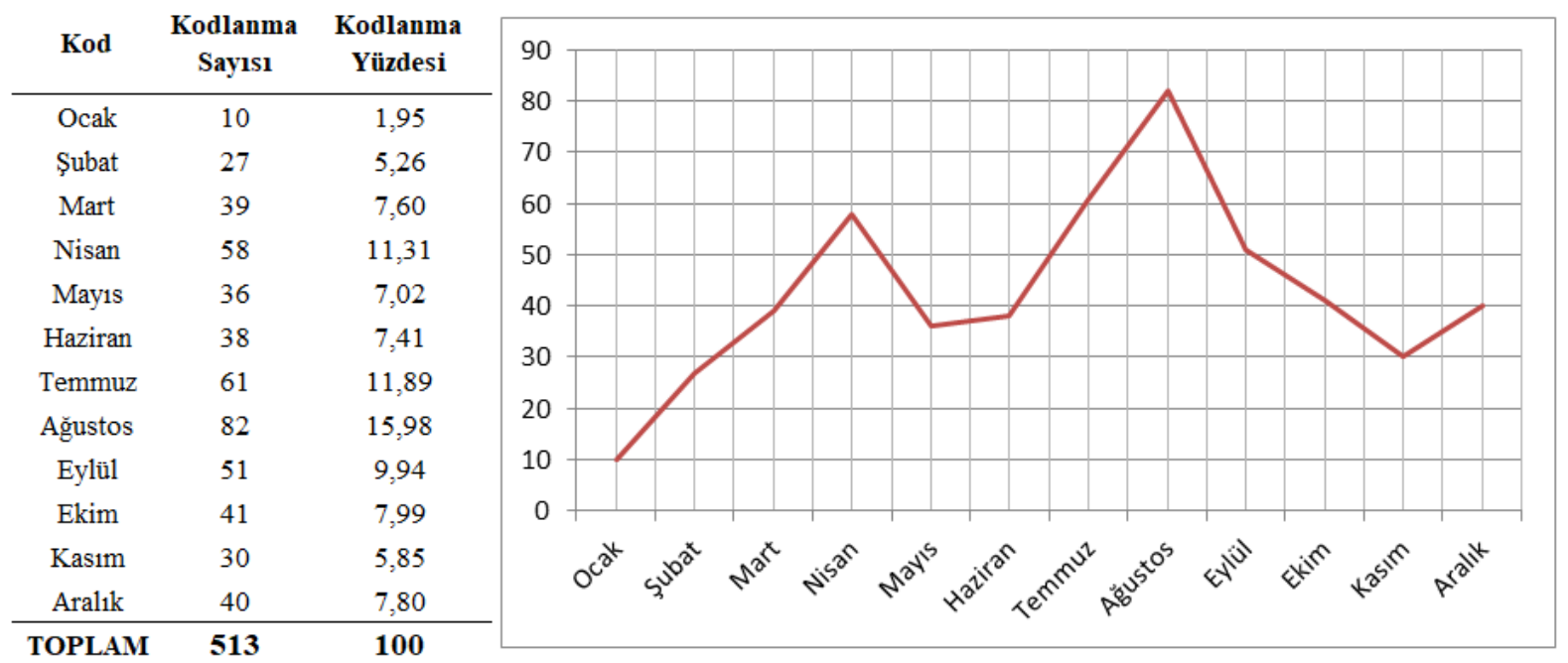

Şekil 2. Elektronik Yorumların Yılın Aylarına Ait Kod Sayıları ve Grafiksel Artış Azalışları

\section{Sille'ye Gelen Ziyaretçi Tipleri}

\begin{tabular}{|c|c|c|c|c|}
\hline Kod Adı & Kod Sayısı & Kod Yüzdesi & $1 \%$ & Bilgeciler \\
\hline Bilgeciler & 357 & 64,44 & 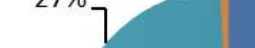 & Erilciler \\
\hline Erilciler & 29 & 5,23 & & Planlavicular \\
\hline Planlayıcılar & 12 & 2,17 & & Prantay ictial \\
\hline Serüvenciler & 2 & 0,36 & & Serüvenciler \\
\hline Zevk Arayıcı & 149 & 26,90 & & Z Zevk Aray $1 c 1$ \\
\hline Öteki Yönlüler & 5 & 0,90 & & Ötel-i Yänlïler \\
\hline Toplam & 554 & 100,00 & & \\
\hline
\end{tabular}

Şekil 3. Elektronik Yorumların Ziyaretçi Tiplerine Göre Kod Sayıları ve Grafiksel Dağılımları

Şekil 3'te elektronik yorumlara göre turist tipleri hakkında yorum yapılmaya çalışılmıştır. Bu kapsamda toplam kodlanan kod sayısı 554 olup 6 farklı kategoriyi kapsamaktadır. Çıkan sonuçlara göre Sille'yi ziyaret eden turistlerin daha çok kültürel ve tarihi merakları olan, seyahatlerinden bilgi ve ders alabilen turist tipi olan Bilgeciler olduğu görülmektedir. Sonrasında ise Zevk Arayıcı olarak adlandırılan ve seyahat, konaklama, ulaşım ve eğlencelerinde keyif ve rahatlık arayan turist tipinin olduğu görülmektedir. Erilci olarak adlandırılan açık hava etkinliklerinden zevk alan, özellikle piknik, mangal ve balık tutma gibi nedenlerle seyahat eden turist tipinin ise üçüncü olarak Sille'yi ziyaret eden turist tipi olduğu görülmektedir. Planlayıcl, Öteki Yönlüler ve Serüvencilerin ise sayılan turist tipleri kadar olmasa da Sille'yi tercih etmiş oldukları söylenebilmektedir. Şekil 4'de elektronik yorumların turist tiplerine göre kod sayıları ve ilgili yapılan birer yorum gösterilmiştir. 


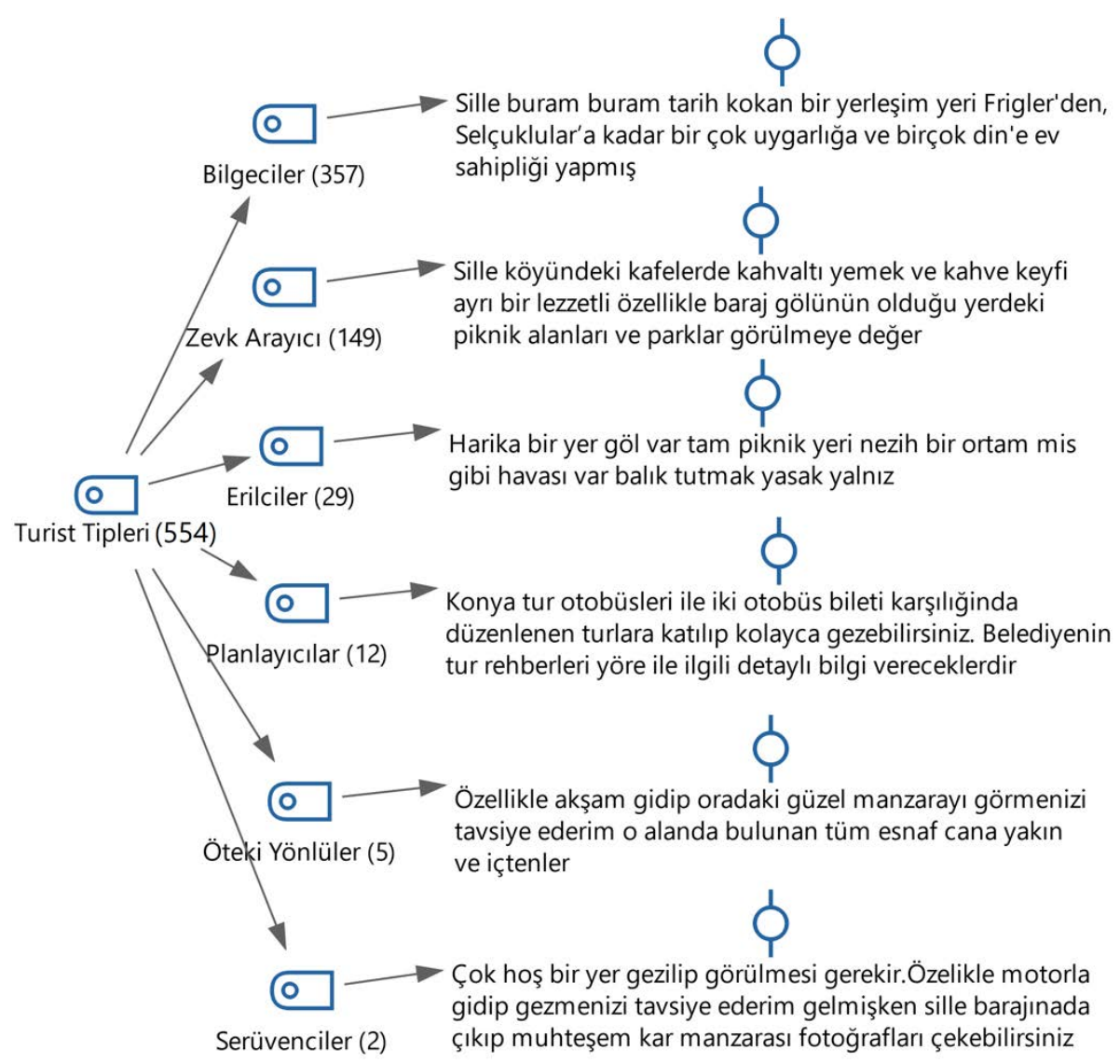

Şekil 4. Elektronik Yorumların Turist Tiplerine Göre Kod Sayıları ve İlgili Yapılan Birer Yorum

\section{Sille Hakkındaki Olumlu-Olumsuz Düşünceler}

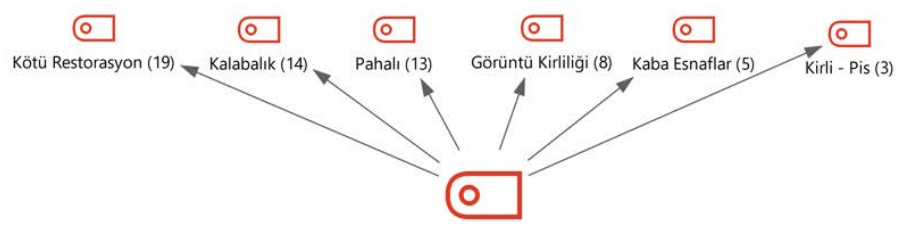

Olumsuz Düşünceler (62)
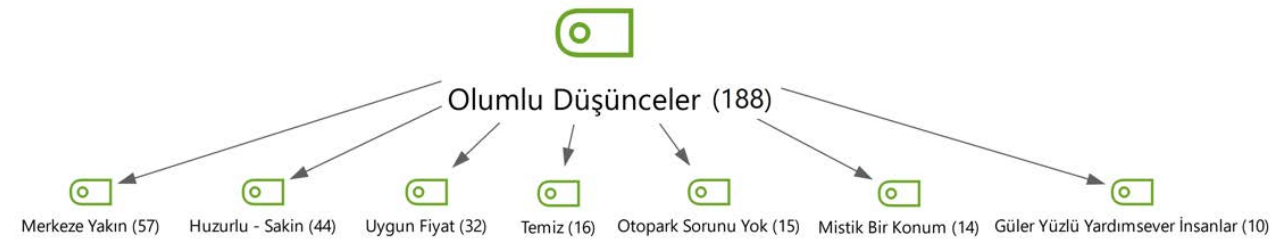

Şekil 5. Elektronik Yorumların Olumlu ve Olumuz Düşüncelere Göre Kod Sayıları

Şekil 5'te görüldüğü üzere Olumlu ve Olumsuz Düşünce olarak kodlanan 250 kod olumsuz düşünce 6, olumlu düşünce ise 7 farklı kategoride kodlanmıştır. Olumsuz Düşünceler olarak kodlanan 62 farklı kod 6 kategoride bir araya getirilmiştir. Sille ile ilgili yapılan elektronik yorumlarda burayı ziyaret eden kişilerin olumsuz olarak yapmış oldukları değerlendirmeler incelendiğinde en çok kodlanan olumsuz kod "kötü restorasyon" kategorisidir. Sonrasında kalabalık, pahalılık, kaba esnaflar ve kirli-pis kategorileri gelmektedir. 


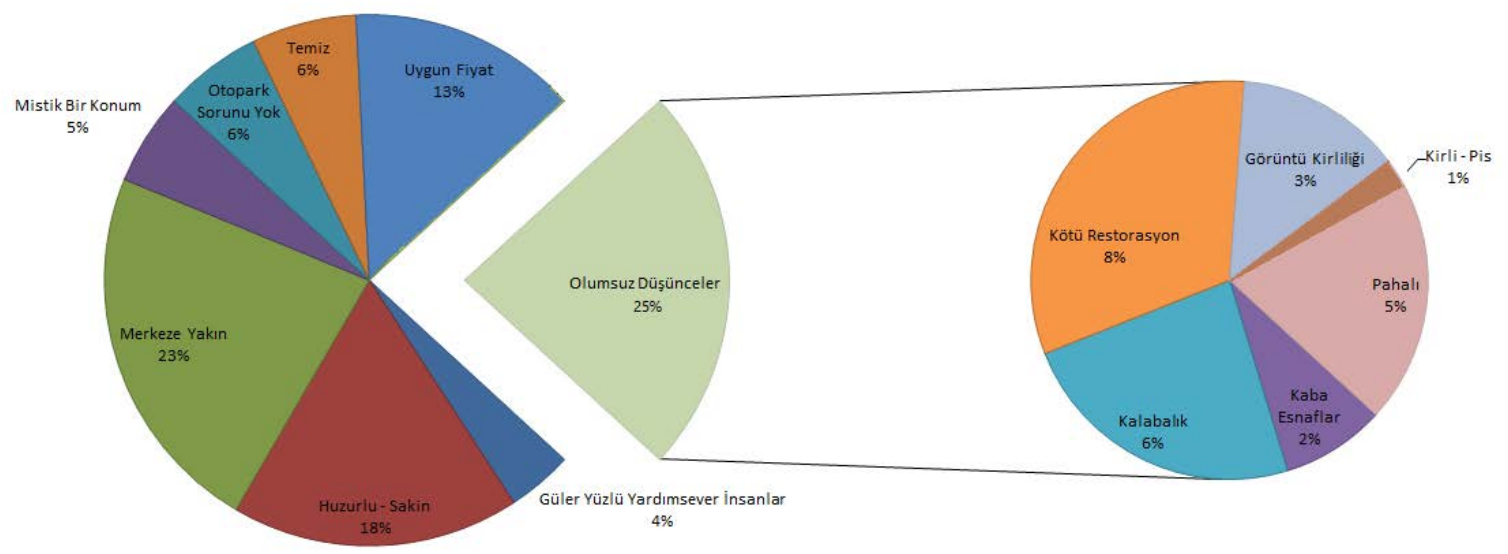

Olumsuz Düșünceler

Şekil 6. Elektronik Yorumların Olumlu ve Olumuz Düşünce Kategorilerine Göre Kodlamalarının Grafiksel Dağılımı

Yapılan Olumsuz yorumlar Olumlu yorumlarla kıyaslandığında Şekil 6'da görüldüğü üzere tüm düşüncelerin \%25'ini oluşturmaktadır. Sille için yapılan elektronik yorumların \%75'i olumlu düşüncelerden oluşmaktadır. Bu düşünceler 188 kodla kodlanmış olup Sille için yapılan en olumlu düşünce kategorisi "Merkeze yakınlıktır." Ziyaretçiler için merkeze yakınlık sonrası en olumlu düşünceler Huzurlu-Sakin olması, Uygun fiyatlı ve Temiz olmasıdır. Bu olumlu düşüncelerin dışında Otopark sorunu olmaması, Mistik bir konuma sahip olması ve güler yüzlü yardımsever insanların bulunması Sille için yapılan olumlu düşünceler arasında yer almaktadır.

\section{Sille'de Ziyaretçilerin Dikkatini Çeken Konumlar}

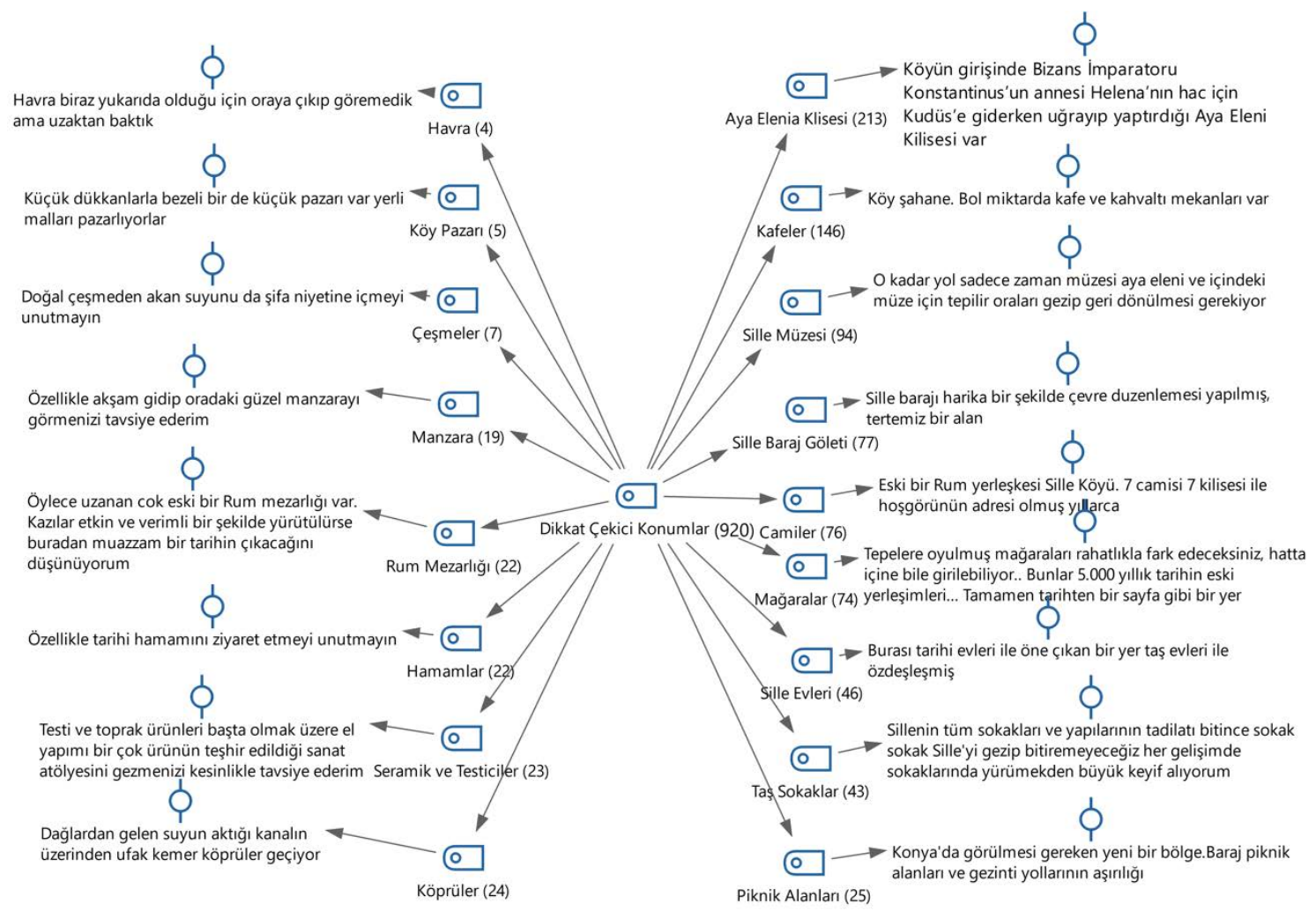

Şekil 7. Elektronik Yorumların Ziyaretçilerin Dikkatini Çeken Konumlara Göre Kod Sayıları ve İlgili Yapılan Birer Yorum 
Şekil 7 incelendiğinde; yapılan elektronik yorumların dikkat çekici konumlar kategorisinde toplam 920 kodla kodlanmış olduğu görülmektedir. Kodların kategorik olarak dağılımlarına bakıldığında en dikkat çeken konumun "Aya Elenia Kilisesi” olduğu görülmektedir. Bu kilisenin tarihi Sille merkezinin en eski yapılarından biri olması, restorasyonu sayesinde günümüze kadar başarılı bir şekilde ulaşmış olması, Hristiyanlık için önem taşıması gibi sebeplerden ötürü Sille'ye seyahat edenlerin yorumları arasında en dikkat çeken konum olduğu söylenebilmektedir. Bu konumu Sille'de yer alan kafeler dikkat çekici özellikleriyle takip etmektedir. Kafelerin fazla sayıda olması büyük oranda dikkat çekmiş seyahat edenler açısından bölgeye gitme sebebi olarak görülmüştür. Sille Müzesi, Sille Baraj Göleti, camileri, mağaraları, Sille evleri, taş sokakları ve piknik alanları Sille'yi ziyaret edenler açısından sırasıyla dikkat çekmiş ve elektronik yorumlarda yer almıştır. Bunların dışında dikkat çekici konumlar; köprüleri, seramik ve testicileri, hamamları, Rum mezarlığı, manzarası, çeşmeleri, köy pazarı ve havrası olarak sıralanmış olduğu görülmektedir. Bu kadar fazla dikkat çeken konuma sahip bir bölge olan Sille yöresi; Müslüman, Hristiyan, Musevi gibi birçok farklı dine sahip kişileri, serüvencisi, zevk arayıcısından bilgecisine farklı birçok turist tipi için merak uyandırabilecek özelliklere sahip olduğu söylenebilmektedir.

\section{Ziyaretçiler Açısından Sille ile Kıyaslaması Yapılan Destinasyonlar}

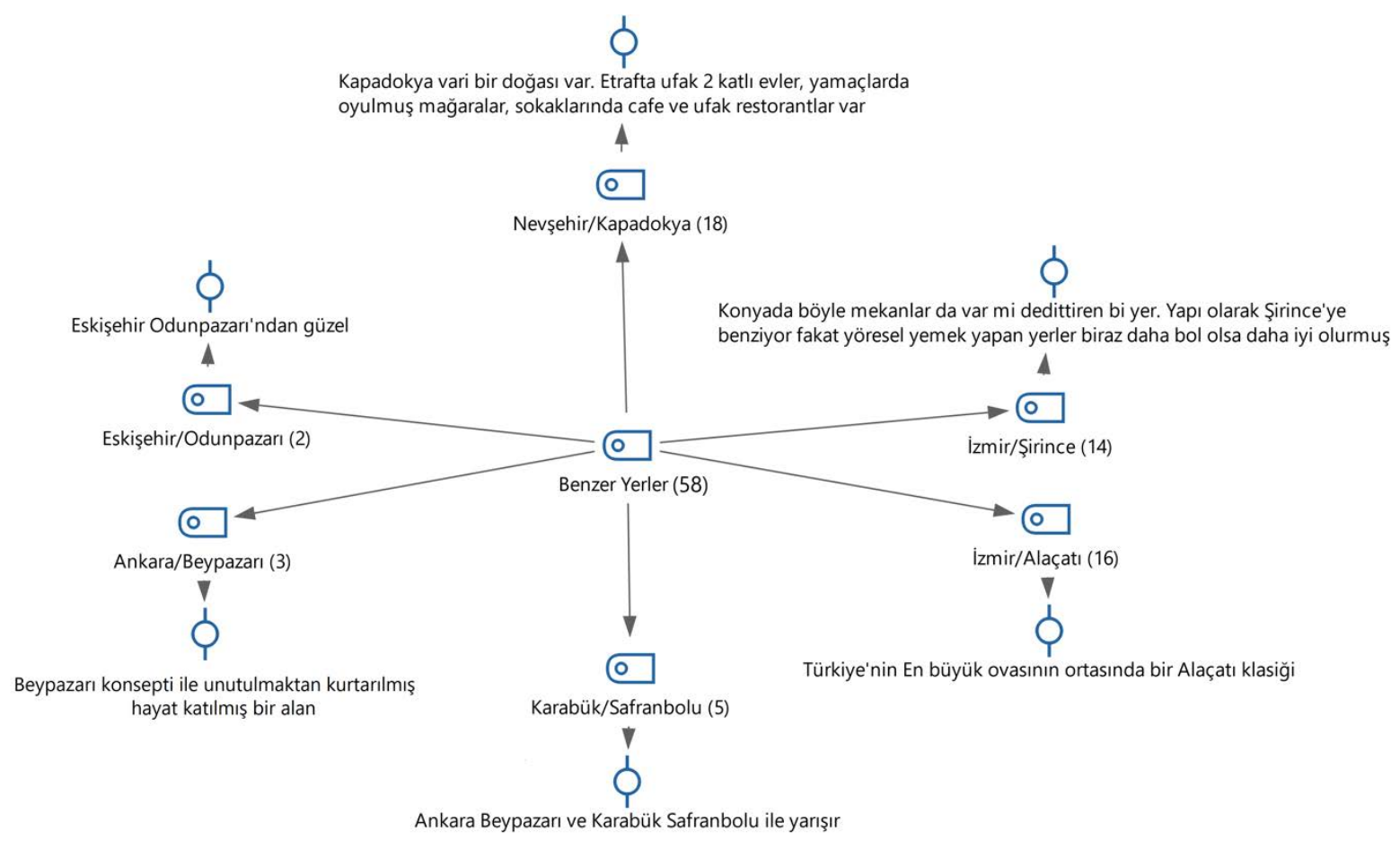

Şekil 8. Elektronik Yorumların Ziyaretçilerin Sille ile Kıyasladıkları Destinasyonlara Göre Kod Sayıları ve Birer Yorum

Şekil 8'de elektronik yorumların ziyaretçilerin Sille ile kıyasladıkları destinasyonlara göre kod sayıları incelendiğinde toplam benzer yerler olarak kodlanan 58 kod bulunmaktadır. Bu kodlar benzerlikleri yapılan kıyaslamalara göre 6 farklı kategoriye ayrılmıştır. Yapılan yorumlarda Sille'nin en çok Nevşehir iline bağlı Kapadokya bölgesine benzetildiği ya da o bölge ile kıyaslandığı görülmektedir. Diğer benzer özellikler taşıyan ya da kıyaslamalar yapılan destinasyonlar ise İzmir/Alaçatı, İzmir/Şirince, Karabük/Safranbolu, Ankara/Beypazarı ve Eskişehir/Odunpazarı bölgeleridir. Turistik açıdan Sille'nin benzetildiği konumlar dikkate alındığında bu bölgenin önemli bir turistik değer olduğu söylenebilmektedir. 


\section{Ziyaretçilerin Seyahat Şekilleri}

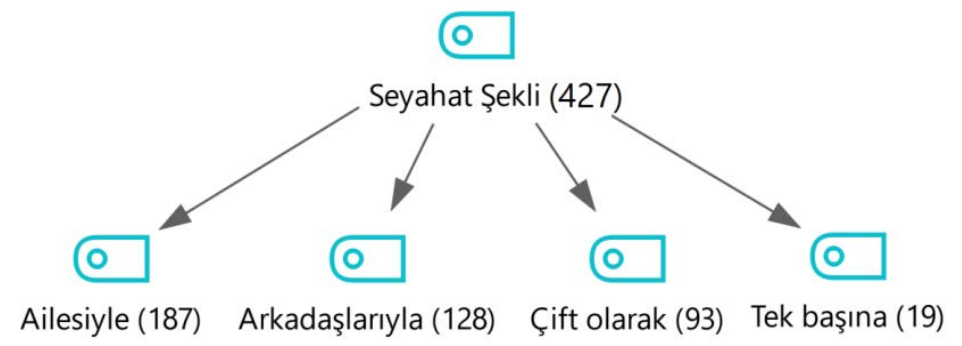

Şekil 9. Elektronik Yorumların Ziyaretçilerin Seyahat Şekillerine Göre Kod Sayıları

Şekil 9'da yapılan elektronik yorumlarda yer alan seyahat şekline bakılmış seyahat edenlerin büyük çoğunluğunun seyahatlerini "aileleriyle" yapmış oldukları görülmektedir. Bununla birlikte Sille'ye arkadaşlarıyla, çift olarak ve tek başına seyahat eden kişilerin de bulunmuş oldukları görülmektedir. Bu durum bu yörenin yalnız ya da kalabalık gruplar olarak da gezilebilen bir bölge olduğunu gösterebilmektedir.

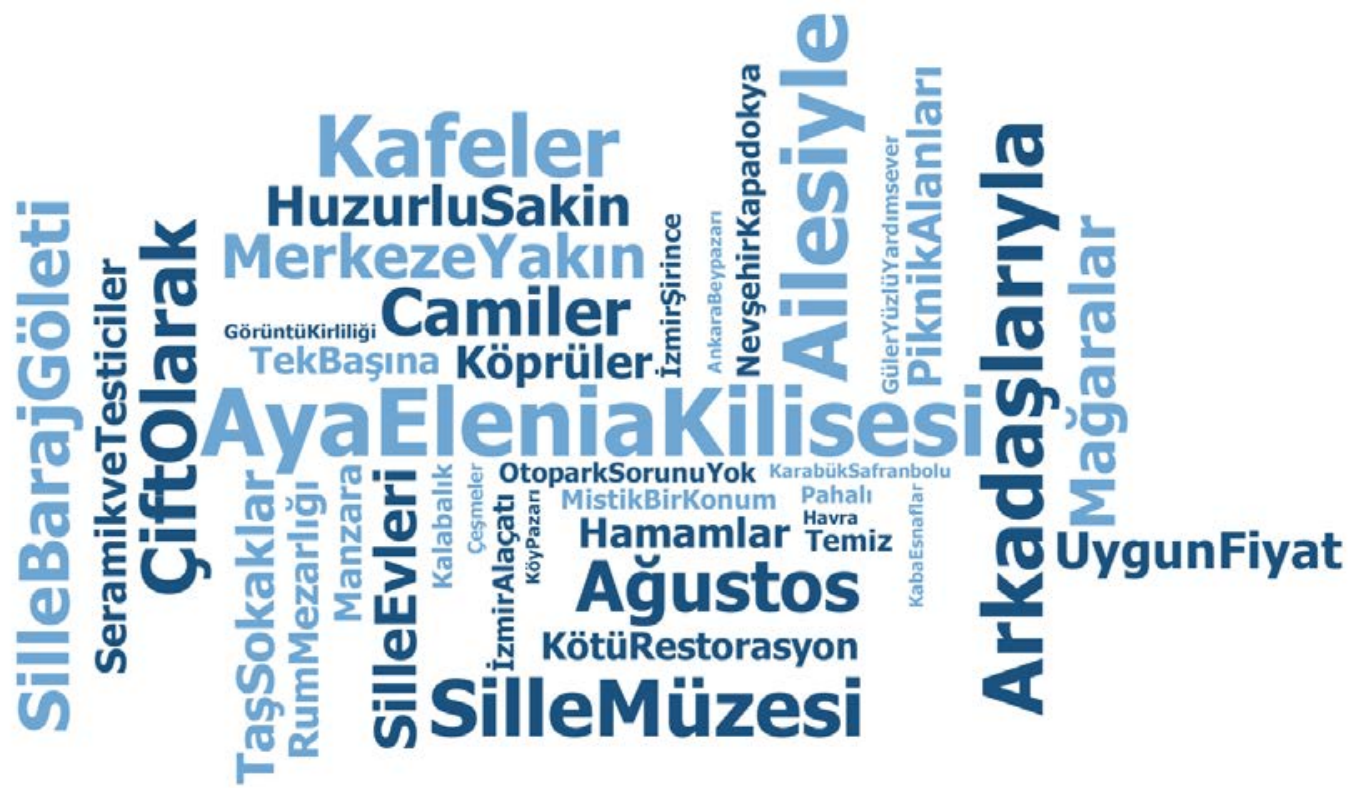

Şekil 10. Elektronik yorumların kodlanan kodlara göre oluşturulan kelime bulutu

Şekil 10'da kodların sıklıklarına göre hazırlanan kelime bulutu yer almaktadır. Ana kodlar bazında çalışmanın genel görünümü ortaya çıkarabilmek amacıyla MAXQDA programı ile kelime bulutu hazırlanmıştır. Kelime bulutu; kodların sıklıklarına göre oluşturulmuş olup en sık yinelenenler ön planda ve kalın olacak şekilde haritada yer verilmiştir. Buna göre en sık rastlanan kodlar Aya Elenia Kilisesi, Sille müzesi, Aile, Arkadaş gibi kavramlar olurken, daha seyrek kodlananlar ise köy pazarı, güler yüzlü, yardımsever gibi kodlar olmuştur. 


\section{TARTIŞMA, SONUÇ ve ÖNERILLER}

Türkiye kültür ve inanç turizmi açısından zengin bir ülkedir. Yüzyıllardır birçok medeniyete ev sahipliği yapması sebebiyle çok sayıda tarihi ve kültürel kaynağa sahiptir. Bu anlamda zengin olan bir il de Konya olup, 8 km kuzeybatısındaki Sille, çok sayıda bilimsel çalışmalara konu olmuştur. Bu çalışmanın yazındaki diğer çalışmalardan farkı, Sille'ye ziyaretçilerin gözünden bakmasıdır. Yerli ve yabancı ziyaretçilerin kendi arzularıyla çok sayıda yorum, eleştiri, beğeni, tavsiye sunduğu web sayfası üzerinden alınan elektronik yorumlar içerik analizine tabi tutularak ziyaretçilerin seyahat profilleri, beğenileri, olumsuz gördükleri alanlar, beğendikleri konumlar, benzettikleri destinasyonlar incelenmeye çalışılmıştır. Ortaya çıkan sonuçlar neticesinde bölge üzerinde söz sahibi olan karar vericilere yol gösterici olmak ve bölgenin kalkınmasına bir nebze de olsa katkı sağlamak çalışmanın amacıdır. Bu kapsamda çalışmada altı temel soru üzerinde durulmuştur. Analiz neticesinde ortaya çıkan bulgulara göre yapılan öneri ve eleştiriler aşağıda sıralanmıştır:

Bilge ve Aktaş (2019), Sille'nin pazarlanmasına yönelik yaptıkları çalışmalarında bölgeye gelen yerli ve yabancı turistlerin yorumlarına önem vermiş ve alınan geri bildirimlerle modern işletmecilik anlayışının birleştirilmesi gerektiğini söylemişlerdir. Bu sayede bölgenin nostaljik havasını yansıtacak ürün ve hizmetlerin sunulabileceğini ve bunun bölgenin öncelikli hedefleri arasında olması gerektiğini ileri sürmüşlerdir. Bu çalışma da ziyaretçilerin yorumlarını inceleyip işletmecilere öneriler sunması bakımından önemlidir. Destinasyonlar için doğal ve tarihi çekiciliklere sahip olmanın yanı sıra bu çekicilikleri pazarlamak da büyük önem taşımaktadır. Bölge yönetimi bilimsel çalışmalar ışığında ziyaretçilerin beklentilerini, beğenilerini ve şikâyetlerini dikkate alarak bölgede faaliyet gösterilen işletmeleri yönlendirebilir. Bölgenin konaklama imkânları ön plana çıkarılarak ziyaretçilerin daha uzun kalması sağlanabilir. Konaklama işletmeleri bölgeye has evlerden oluşturularak ziyaretçilere otantik deneyimler yaşama imkanı sunulabilir.

Çalışmada Şekil 2' de ziyaretçilerin en çok Ağustos ayında bölgeyi ziyaret ettikleri görülmüştür. Bu durum daha çok yürüyerek gezilen açık hava bölgesi olması sebebiyle insanların sıcak havayı tercih ettiklerini göstermektedir. Kapalı alan etkinliklerinin artırılması yoluyla yılın diğer aylarına ziyaretçi yoğunluğu paylaştırılabilir. Böylece bölgenin taşıma kapasitesi uygun hale getirilip, tarihi ve kültürel eserlerin yıpranma oranı azaltılabilir. Ziyaretçilerin hoşça vakit geçirebilecekleri açık hava tiyatroları, konserler, sergiler bölgede düzenlenebilir. Bunun yanı sıra bilimsel etkinlikler düzenlenerek otantik evlerde sunum yapabilme imkânı sunulabilir. Kongre turizmi açısından büyük potansiyele sahip olan Konya ilinde düzenlenen kongre ve fuar ziyaretçi programlarının sosyal etkinlik günlerine Sille eklenerek farklı amaçlarla Konya'ya gelen yerli ve yabancı ziyaretçilerin bölgeyi de gezmiş olması sağlanabilir. Kongrelerin en çok Mayıs ve Eylül aylarında rağbet gördüğü düşünüldügünde Ağustos ayındaki yoğunluk diğer aylara da yayılabilir.

Çalışmada Şekil 4'te görüleceği üzere Sille, bilgeci turist tipinin dikkatini daha çok çekmiştir. Diğer turist tiplerinin hoşuna gidecek etkinliklerin artırılması yoluyla ziyaretçi çeşidinde farklılaşmaya gidilebilir, daha çok ziyaretçi ağırlanabilir. Hedef kitlenin çeşitlenmesi için zevk arayıcılara, serüvencilere, erilcilere, planlayıcılara ve öteki yönlülere özel aktiviteler planlanarak rekreasyon ve animasyon hizmetleri artırılmalıdır. Örneğin zevk arayıcı turist tipi için müzikli eğlence mekânları artırılabilirken, özgüvenciler için sıradışı etkinlikler düzenlenebilir. Planlayıcı tip için bölgenin daha çok paket turun içerisinde yer alması sağlanabilir. Erilciler için kamp yapma ve dağ yürüyüş açık hava etkinlikleri düzenlenebilir. Öteki yönlü ziyaretçi tipi için ise daha fazla insanla iletişim kurup kaynaşabileceği şekilde etkinlikler düzenlenebilir. Bunlar da yarışmalar, kareoke partileri şeklinde olabilir. 
İnanç turizmi kaynaklarının korunmuş olması ve bakımının sürekliliği bu turizm çeşidinin gelişmesi ile yakından ilişkilidir. Korunmuş kaynaklar bölgenin cazibesine katkı sunmaktadır. Kimi zaman bütçe, uzmanlık ve restorasyon gibi konularda sorunlar yaşanabilmektedir. Bu sebeple sosyo-kültürel ve tarihi kimliğin temelini oluşturan öge ve yapıların özgünlüklerinin korunması önem arz etmektedir (Okuyucu ve Somuncu, 2013: 640). (Erdem vd., 2010) yılında Sille üzerine yaptıkları çalışmalarında bölgenin sosyal yapısında değişiklikler ve koruma çalışmalarına az ilgi gösterildiğini söylemektedirler. Dolayısıyla bozulma ve köhneleşme olduğunu öne sürmüşlerdir. Buna çözüm olarak ise tescilli binaların dokuya uygun restorasyonu ile çevresel kalitenin artırılabileceğini önermişlerdir. Ayrıca turizm ve ticaret amaçlı kullanılan bazı konutlarda da çevresel kalitenin artırılması ve bölgesel korumanın gerekli olduğunu vurgulamışlardır. Bu çalışmada da Şekil 5.'te de görüleceği üzere Sille üzerine yapılan elektronik yorumlarda kötü restorasyonlar en fazla kodlanan olumsuz düşünce olmuştur. Bu anlamda Erdem ve arkadaşlarının çalışmasının desteklendiği söylenebilir. Restorasyonların aslına uygun şekilde yapılabilmeleri için sektör çalışanlarının eğitim programlarında iyileştirmelere gidilebilir. Sanat tarihi, dinler tarihi, mimarlık, arkeoloji vb. alanlardaki akademisyenlerden bilimsel danışmanlık hizmetleri alınabilir.

Çakıcı ve Özdamar (2012), Şanlıurfa'ya kültür turizmi kapsamında gelen yerli turist profilleri ve karşılaş̧ıkları sorunlar üzerine yaptıkları çalışmalarında alt yapı sorunlarının ve çevre ve gürültü kirliliğinin öncelikli olduğu sonucuna varmışlardır. Giderilmesi için ise karar vericilerin önlem alması gerektiğini söylemişlerdir. Bu çalışmada Sille için ise üst yapılarla ilgili eleştiriler daha fazla gelmiştir. Şekil 6'ya göre ise Çakıcı ve Özdamar'ın çalışmalarına benzer şekilde çevre kirliliği konusu da ziyaretçileri rahatsız eden konulardan olmuştur. Yeşil yönetimin hayatımızın her alanına girdiği günümüzde çevreci yaklaşımlar sadece planlamalarda kalmamalı, uygulamalarla hayata geçirilmelidir. Bu kapsamda atık yönetimi, geri dönüşümler, gürültü kirliliği, kaynak kullanımı, akıllı sistemler gibi konularda yerel halk, ziyaretçiler ve işletme sahipleri ile çalışanlar bilinçlendirilmelidir.

Çınarlı ve Ay (2018), Sille halkının sürdürülebilir turizm konusunda görüşlerini aldıkları çalışmalarında yurtdışından gelen turistlerin Sille'de en dikkat çekici unsur olarak Aya Elenia Kilisesi'ni gördüklerini söylemişlerdir. Bu çalışmanın bulguları arasında da Şekil 7'de Aya Elenia Kilisesinin en fazla bahsedilen konum olduğu görülmüştür. Dolayısıyla iki çalışmanın birbiri ile tutarlı olduğu sonucu ortaya çıkmaktadır. Kilise Hristiyanlık inancına ait olsa da farklı inanışa sahip kişilerin de merakını cezbetmektedir. Aya Elenia Kilisesi'nin yanında diğer çekiciliklerin de ilgi görmesi için bölgede yer alan tanıtım bilbordları, broşürler, yol tarif levhaları artırılabilir. Turist rehberleri tanıtımlarının arasında geri planda kalmış çekicilikleri ön plana çıarabilirler.

Çalışmada Sille Türkiye'deki benzer alanlar arasında Şekil 8'den de görüleceği üzere en çok Nevşehir ilindeki Kapadokya bölgesine benzetilmiştir. Kapadokya'nın tanınırlığı ve ziyaretçi sayısının fazlalığı düşünüldüğünde Sille'de bu anlamda bazı tanıtım ve pazarlama faaliyetlerinde eksiklikler olduğu sonucuna ulaşılabilir. Sille'nin markalaşması için profesyonel ekiplerle çalışılması bölgenin gelişmesi bakımından önemli görülmektedir. Yerel yönetimlerin sahip oldukları bütçelerin önemli bir kısmını tanıtım ve pazarlama kalemlerine ayırmaları ve başarısı ispatlanmış ekiplerle tanıtım ve pazarlama faaliyetlerini yürütmelerinin etkili olacağ düşünülmektedir.

Çalışmada Şekil 9'a göre ziyaretçilerin Sille'ye en çok aileleri ile birlikte geldikleri görülmüştür. Otantik bir şehir olan Sille aile fertlerinin hep birlikte hoşça vakit geçirebileceği bir merkez olmuştur. Kitlesel seyahatler ve grup turları için kalabalıkla zevk alınabilecek paket turlar oluşturulabilir. Çocuklar için oyun alanları ile sanatsal ve bilimsel etkinlik alanları oluşturulabilir. Yaşlılar için kolay yürüyebilecekleri yürüyüş parkurları, dinlenme olanakları, gürültüsüz ortamlar oluşturulabilir. Ayrıca anılarını tazeleyebilecekleri fotoğraf sergileri, antik 
eşya sergileri hazırlanabilir. Sille ayrıca bireysel ziyaretçiler için de ulaşım kolaylığı, yeme-içme ve konaklama imkânlarına sahiptir. Bu anlamda yalnız dolaşmayı seven bireysel ziyaretçilerin hoşuna gidecek şekilde ürün çeşitlendirmesine gidilebilir. Bireysel turistlerin genellikle tercih ettiği ucuz ve salaş konaklama işletmesi olan hostellere bölgede yer verilebilir. Yeme içme açısından da bireysel gezginlerin bütçelerine uygun alternatifler ortaya çıkarılabilir. Sokak yiyecekleri diye adlandırılan simit, ekmek arası köfte, kokoreç gibi yiyecek türleri çoğaltılabilir.

Çalışma Konya'nın önemli bir çekiciliği olan Sille ile sınırlandırılmıştır. Konya, kültür ve inanç turizmi bakımından zengin bir ildir. Benzer bir çalışma diğer kültür ve inanç merkezleri için gerçekleştirilebilir ve çeşitli kıyaslamalarla merkezler arasındaki benzerlik ve farklılıklar ortaya konulabilir.

Çalışma, birçok bilimsel araştırmada olduğu gibi bazı kısıtlılıklara sahiptir. Çalışmada seyahat profilleri incelenirken turistlerin tipleri, seyahat zamanları ve seyahatlerini kimlerle gerçekleştirdikleri konuları üzerinde durulmuştur. Bunlara ilave olarak ziyaretçilerin gelir durumu, yaş durumu, cinsiyetleri, harcama miktarları, konaklama süreleri için de çeşitli kodlar kullanılarak daha genişletilmiş bir inceleme yapılabilir. Ayrıca bölge hakkındaki olumlu ve olumsuz görüşler alınmıştır ancak bunlara yönelik bir öneri araştırmasına gidilmemiştir. Öneriler için de ayrı kodlama yapılabilir.

\section{KAYNAKÇA}

Altunışık, R., Coşkun, R., Bayraktaroğlu, S., ve Yıldırım, E. (2015). Sosyal Bilimlerde Araştırma Yöntemleri: SPSS Uygulamalı,(8. Baskı), Adapazarı: Sakarya Yayıncılık.

Avcıkurt, C. (2003). Turizm Sosyolojisi,(1. Baskı), Balıkesir: Detay Yayıncılık.

Belber, B. G. (2011). Nevşehir'e gelen "İspanyolca Konuşan" turistlerin profilini belirlemeye yönelik bir araştırma. Eskişehir Osmangazi Üniversitesi Sosyal Bilimler Dergisi, 12(2), 31-60.

Bilge, F. A., ve Aktaş, E. (2019). Nostaljik Bölge Pazarlaması: Sille Örneği. Selçuk Üniversitesi Sosyal ve Teknik Araştırmalar Dergisi(18), 1-9.

Chang, Y. C., Ku, C. H., and Chen, C. H. (2019). Social media analytics: Extracting and visualizing Hilton hotel ratings and reviews from TripAdvisor. International Journal of Information Management, 48, 263-279.

Çakıcl, A. C., ve Özdamar, M. (2012). Şanlıurfa'ya Kültür Turizmi Kapsamında Gelen Yerli Turistlerin Profili, Şanlıurfa'yı Tercih Nedenleri ve Karşılaştıkları Sorunlar Üzerine Bir Araştırma. Seyahat ve Otel İşletmeciliğgi Dergisi, 10(2), 43-52.

Çınarlı, E., ve Ay, H. M. (2018). Sürdürülebilir Turizm Konusunda Yerel Halkın Görüşlerinin Belirlenmesi: Sille Örneği. Selçuk Üniversitesi Sosyal Bilimler Meslek Yüksekokulu Dergisi, 21(2), 239250.

Doğan, A., ve Ertan, T. (2016). Siyasal iletişim aracı olarak ABD Başkanlık Seçimlerinde Twitter'ın Kullanımı: Hillary Clinton ve Donald Trump örneği. Atatürk Iletişim Dergisi, (11), 139-158.

Drule, A. M., Băcilă, M. F., Ciornea, R., and Chiş, A. (2015). Segmenting visitors encountered at sacred sites based on travelling motivations and constraints. Current Science, 109(2), 265-270.

Erdem, R., Yıldırım, H., Çiftçi, Ç., Dülgerler, O. N., Çıbıkdiken, A. O., Levend, S., ve Erdoğan, A. (2010). Sille, Bir Koruma Geliştirme Planı ve Sonrası. Selçuk Üniversitesi Mühendislik, Bilim ve Teknoloji Dergisi, 25(2), 25-46.

Eröz, S. S., ve Doğdubay, M. (2012). Turistik ürün tercihinde sosyal medyanın rolü ve etik ilişkisi. Dokuz Eylül Üniversitesi İktisadi İdari Bilimler Fakültesi Dergisi, 27(1), 133-157. 
Ertaş, Ş., Sönmez, E., Sadıklar, Z., and Kafil, P. (2016). History Through Image and Symbol: Konya/Sille. 2nd ICNTAD'16 International Conference on New Trends in Architecture and Interior Design. Zagreb/Croatia. ss: 19-22.

Hamilton, W. J. (1842). John, Researches in Asia Minor, Pontus and Armenia, Vol. I-II. In. London: John Murray.

Karataş, Z. (2015). Sosyal bilimlerde nitel araştirma yöntemleri. Manevi Temelli Sosyal Hizmet Araştirmalari Dergisi, 1(1), 62-80.

Kaynak, İ. H. (2010). İnanç turizminin medeniyetler arası işbirliğine etkileri: Türkiye örneği. Selçuk Üniversitesi Sosyal Bilimler Meslek Yüksek Okulu Dergisi, 13(1-2), 119-126.

Keskin, E., ve Çetinkaya, S. (2018). Hac ve Manevi Turizm (Editör) Ş. Aydın ve M. Boz, Turizmde Güncel Konu ve Eğilimler II içinde. Ankara: Detay Yayıncllık.

konyakultur.gov.tr. (2020). Sille kültür vadisi, https://konyakultur.gov.tr/index.php?route=modules/to wns\&town_id=11>[Erişim tarihi: 18.08.2020]

Krippendorff, K. (2004). Content Analysis: An introduction to its Methodology, (2. Bask1), Thousand Oaks: Sage Publications.

Kuyucu, S. (2017). Kültür Turizmi Kapsamında Inanç Turizminin Yerel Halk Tarafından Algılanması: Bilecik Örneğgi. (Yüksek Lisans Tezi), Sakarya Üniversitesi, Sakarya.

Okuyucu, A., ve Somuncu, M. (2013). Türkiye'de inanç turizmi: bugünkü durum, sorunlar ve gelecek. International Conference on Religious Tourism and Tolerance, 09-12 May 2013. Konya / Turkey. ss: 9-12.

Özönder, H. (1999). Yüzyıllar Boyunca Sille'de Halıcılık ve Sille Halılarının Karakteristik Özellikleri. Erdem, 10(30), 535-544.

Richards, G. (2018). Cultural tourism: A review of recent research and trends. Journal of Hospitality and Tourism Management, 36, 12-21.

Rızaoğlu, B. (2012). Turizm Davranışı,(3. baskı): Detay yayıncılık.

T.C. Kültür ve Turizm Bakanlığı. (2020). İnanç Turizmi. https://mersin.ktb.gov.tr/TR-73394/inancturizmi.html>[Erişim tarihi: 23.08.2020]

Tapur, T. (2009a). Konya İlinde Kültür ve Inanç Turizmi. Journal of International Social Research, 2(9), 473-492.

Tapur, T. (2009b). Konya'da tarihi bir yerleşim merkezi: Sille. Türk Coğrafya Dergisi, 53, 15-30.

United Nations. (2010). International Recommendations for Tourism Statistics 2008, (Vol. Economic \& Social Affairs), New York: Department of Economic and Social Affairs Statistics Division, United Nations Publication.

Üzümcü, T., Çelik, A., ve Karataş, M. (2017). Koruma-Kullanma İkileminde Sürdürülebilirlik ve Kırsal Turizm: Konya-Sille Örneği. Turkish Journal of Scientific Reviews, 10(1), 53-64. 